\title{
Molecular Docking Studies of Potential Multifloroside and Trimyristin as Inhibitor for Anti Malaria
}

\author{
Nya Daniaty Malau ${ }^{1 *}$, St Fatimah Azzahra ${ }^{2}$ \\ ${ }^{I}$ Department of Physics Education, Universitas Kristen Indonesia, Jakarta, Indonesia \\ ${ }^{2}$ Department of Chemistry Education, Universitas Kristen Indonesia, Jakarta, Indonesia \\ Corresponding Email: malaunyadaniaty@gmail.com
}

\begin{abstract}
This study aims to analyze the potential of Multifloroside and Trimyristin as inhibitors of plasmepsin compounds as anti-malaria. The method used in analyzing the potential of Multifloroside and Trimyristin ligands as antimalarials is by insilico approach through tethering using Autodock Vina. Based on the free energy parameters of the Multifloroside molecular tethering, a value of -9.0 was obtained and for the Trimyristin molecule a value of -6.4 was obtained with 5 replications each. The free energy value of Multifloroside and Trimyristin ligands is negative, this means that Multifloroside and Trimyristin ligands are stable for use as Plasmepsin inhibitors. Because the lower the free energy of a molecule, the more stable the molecule is. But if you see the most potential between Multifloroside and Trimyristin, Multifloroside is better than Trimyristin ligands. Analysis based on hydrogen bonding parameters contained 1 hydrogen bond each showed that the stronger the Multifloroside and Trimyristin inhibitors bind to the receptors. For the Multifloroside ligand, the hydrogen bond formed is UNK-H ligand, whereas for Trimyristin ligand, the hydrogen bond formed is SER218-HN residue. The small number of hydrogen bonds does not affect the stability of the ligand and receptor bonds.
\end{abstract}

Keywords: docking, inhibitor, cyanidin, antimalaria

\section{INTRODUCTION}

Malaria is a dangerous parasitic disease in the world. Around 2.3 billion or $41 \%$ of the world's population is at risk of contracting malaria. Every year, an estimated number of malaria cases are 300500 million with 1.5-2.7 million deaths. Malaria is stated as a major public health problem in 9 Southeast Asian countries including Myanmar, Kampuchea, Indonesia, Laos, Malaysia, the Philippines, Singapore, Thailand and Vietnam. Reportedly the number of malaria outpatients increased from 3.2 million (2001) to 8.4 million (2006), with deaths from 100,504258,548 people and very widespread in 109 endemic countries (Harijanto, 2000).

In Indonesia, malaria is a contagious disease that is still a major public health problem. Malaria is very influential on morbidity and mortality rates for infants, toddlers and mothers giving birth, besides that malaria also directly decreases work productivity. Malaria is one of the priorities in eradicating infectious diseases that have become an integral part of the development of the health sector (Kemenkes, 2006).

Malaria is more common in children under 5 years of age (Soedarto, 2009). Malaria has existed since
3000 years ago (Widoyono, 2011). The cause of malaria is the Plasmodium parasite, while its transmission to humans is mediated by female Anopheles mosquitoes. Malaria remains a major health problem in both the tropics and subtropics such as in Brazil, Southeast Asia and throughout subSaharan Africa

Based on WHO (2015) the occurrence of malaria in humans is caused by parasites of the genus Plasmodium, namely Plasmodium falciparum, Plasmodium vivax, Plasmodium malariae, Plasmodium ovale and Plasmodium knowlesi. Kementrian Kesehatan (2012) divides malaria into 5 types, namely (1) Malaria falciparum. Malaria is caused by Plasmodium falciparum which is characterized by a fever that appears intermittently and can also be continuous. This type of malaria that often causes death, (2) Malaria vivax caused by Plasmodium vivax. The symptoms are fever that will recur with a fever-free interval for two days, (3) Malaria ovale whose cause is Plasmodium ovale. Symptoms are recurring fever with a fever-free interval of two days, (4) Malaria malariae caused by 
Plasmodium malariae. Fever occurs repeatedly with fever-free intervals for three days and (5) Malaria knowlesi caused by Plasmodium knowlesi and is characterized by symptoms of intermittent fever and can be continuous.

Various attempts were made to overcome malaria. One of them is with efforts to find new anti-malaria drugs. The discovery of new drugs is generally done in trial and error (trial and error). This will cost a very large amount, considering that from 8,000 to 10,000 new compounds resulting from synthesis or originating from natural sources, after going through various tests such as physical tests, chemical tests, activity tests, toxicity tests, pharmacokinetic tests then pharmacodynamic tests, until tests clinically, there is probably only one compound clinically that can be used as medicine. Starting from synthesis or extraction, pharmacological testing, clinical evaluation and registration approval takes approximately 10 years. This is due to the strict regulation of new drugs that are licensed to be marketed. This means that for the development of new malaria drugs to remain economically viable, basic thinking strategies are needed in conducting research with a small number of selected compounds, and how to design good compounds.

One method of finding new antimalarial drugs is by using computational studies or so-called Docking. Computational studies are a branch of chemistry using theoretical chemical results, then translated into computer programs to calculate the properties and changes of molecules and by simulating large systems (macromolecules such as proteins and nucleic acids) and large systems that can includes the study of molecular conformation and changes (for example, the process of protein denaturation), and phase changes, and estimating macroscopic properties (for example, specific heat) based on behavior at the atomic and molecular level (Siswandono, 2000).

Docking is a method used to predict the orientation of one molecule to another when electrostatic interactions occur with one another to form stable bonds (Lengauer \& Rarey, 1996). The principle of docking is the technique of placing the ligand into the active side of the receptor followed by molecular evaluation based on the conformational structure and electrostatic properties (Kroemer, 2003). Docking simulations can be used to obtain a better understanding of the mechanism of action of a chemical compound or macromolecules such as proteins or peptides, on a molecular scale so that it is possible to design structural-based drugs (Ali, 2007). The function of docking is to include making ligandprotein conformations called "poses" possible on protein-binding pockets. In general, the docking program performs the process of finding positions with flexible ligand patterns and rigid proteins. Each position is evaluated (assessed) based on its shape and characteristics such as electrostatic to find the most preferred position (Okimoto, et.al. 2009). By using the docking method, the search for new anti-malaria compounds does not need to be costly, because it can be done using computer simulations.

In this research, molecular docking analysis will be conducted to design a new antimalarial drug. The receptors used were plasmepsin and the ligands analyzed were Multifloroside and Trimyristin ligands. The observed parameters are the value of the free bond energy $(\Delta \mathrm{G})$ produced and the number of hydrogen bonds between the receptors and ligands formed.

\section{METHOD}

The research conducted was in silico research using computer simulations. The tool used is a set of computer equipment along with complementary software that has 8GB Random Access Memory (RAM) specifications, an Intel Core i7 $3.3 \mathrm{GHz}$. While the software used is Autodock vina 1.1.1 for docking simulation and VMD (Visual Molecular Dynamics Program) version 1.9.1, Autodock tools, and Pymol for preparation and analysis.

In this study the material used is in the form of a chemical structure of plasmepsin receptors which can be obtained from the Protein Data Bank website (PDB) and the chemical structure of Multifloroside and Trimyristin ligands can be obtained from the PubChem website (Berman et.al., 2000).

This research is generally divided into three parts, namely the search for receptor and ligand structures, docking simulation, and evaluation of docking results. The target protein structure used is the plasmepsin enzyme which can be downloaded through the site www.rscb.org/pdb, while the structure of the ligand is obtained by downloading from the PubChem website. The structure data needs to be changed from the extension.pdb format to the .pdbqt format. The .pdb format in the ligand and receptor shows no charge on the molecule, while the .pdbqt format shows the partial charge on each atom.

Another preparation process carried out before docking simulation is carried out is identifying the amount of rotatable bond to determine the flexibility of a ligand. The more rotatable bonds, the more flexible the ligand used. Another process is the determination of a grid box to determine the ligand rotation space of the receptor position. This study uses 
a large grid box, so that the ligands can rotate freely to find the most stable place on the receptor (Lipinski et.al. 1997). Data structure of the molecule and others need to be stored in one folder in one working directory to facilitate our work. After the target protein and ligand structure is obtained, the docking simulation is ready to be performed using AutoDockVina software. In this study 10 docking was performed on each ligand to get the best value of Gibbs free energy $(\Delta \mathrm{G})$. The last step is the evaluation of the conformation of molecular structures resulting from docking using VMD and PyMol software. The results obtained are the interaction between Multifloroside ligand and Trimyristin with the plasmepsin enzyme.

\section{RESULT AND DISCUSSION}

\subsection{Reseptor of identification}

The three-dimensional structure of the Plasmepsin enzyme is downloaded through the GDP bank. The three-dimensional structure of the plasmepsin enzyme was obtained from the results of crystallization using X-ray diffraction with a resolution of 1.9 Armstrong. The plasmepsin enzyme has a GDP 1LEE code and has a residual length of 331 (Asojo, 2002). Visualization of PDB 1LEE-coded protein was done using VMD 1.9.3 software. Visualization results show that there is one chain, A, which is bound to one ligand, R36. In this study, the plasmepsin structure used was the original structure without additional ligands.

\subsection{Reseptor of identification}

The ligands used are Multifloroside Compound and Trimyristin. Multifloroside compound is a glycoside compound derived from the Oleaceae family with original plant species namely jasminum multiflorum or known by the name of gambir jasmine (Aceh). Glycoside compounds are known to have antimalarial activity.
Table 1: Multifloroside compounds

\begin{tabular}{|c|c|}
\hline PubChem CID & 10919492 \\
\hline IUPAC Name & $\begin{array}{l}\text { 2-(3,4-dihydroxyphenyl)ethyl } \\
\text { (4S,5E,6S)-4-[2-[2-(3,4- } \\
\text { dihydroxyphenyl)ethoxy]-2- } \\
\text { oxoethyl]-5-(2- } \\
\text { hydroxyethylidene)-6- } \\
{[(2 S, 3 R, 4 S, 5 S, 6 R)-3,4,5-} \\
\text { trihydroxy-6- } \\
\text { (hydroxymethyl)oxan-2-yl]oxy- } \\
4 H \text {-pyran-3-carboxylate }\end{array}$ \\
\hline Structure & \\
\hline Molecular Formula & $\underline{\mathrm{C}}_{32} \underline{\mathrm{H}}_{38} \underline{\mathrm{O}}_{16}$ \\
\hline Chemical Names & ZINC162063889 \\
\hline Molecular Weight & $678.6 \mathrm{~g} / \mathrm{mol}$ \\
\hline $\begin{array}{l}\text { Hydrogen Bond } \\
\text { Donor Count }\end{array}$ & 9 \\
\hline $\begin{array}{l}\text { Hydrogen Bond } \\
\text { Acceptor Count }\end{array}$ & 16 \\
\hline
\end{tabular}

Trimyristin compound is a triglyceride compound derived from the family Euphorbiaceae with plant species origin namely Aleurities moluccana or better known as hazelnut.

Trimyristin is also found in Myristica fragrans or better known as nutmeg which is derived from the family Myristicaceae. Trimyristin is used as a lipid nanoparticle combined with curcuminoids in the treatment of malaria. Triglyceride compounds are also involved in the treatment of malaria as an oil phase transporting antimalarial substances. 
Table 2: Trimyristin compounds

\begin{tabular}{|l|l|}
\hline PubChem CID & 11148 \\
\hline IUPAC Name & $\begin{array}{l}2,3 \text {-di(tetradecanoyloxy)propyl } \\
\text { tetradecanoate }\end{array}$ \\
\hline Structure & \\
\hline $\begin{array}{l}\text { Molecular } \\
\text { Formula }\end{array}$ & C45 $186 \mathrm{O}_{6}$ \\
\hline $\begin{array}{l}\text { Chemical Names } \\
\text { TRIMYRISTIN } \\
555-45-3 \\
\text { propane-1,2,3-triyl tritetradecanoate } \\
\text { Glycerol trimyristate } \\
\text { Myristin }\end{array}$ \\
\hline $\begin{array}{l}\text { Molecular } \\
\text { Weight }\end{array}$ & $723.2 \mathrm{~g} /$ mol \\
\hline $\begin{array}{l}\text { Hydrogen } \\
\text { Bond Donor } \\
\text { Count }\end{array}$ & 0 \\
\hline $\begin{array}{l}\text { Hydrogen Bond } \\
\text { Acceptor Count }\end{array}$ & 6 \\
\hline
\end{tabular}

\subsection{Bonding Energy (Gibbs Free Energy)}

Table 3: Gibbs free energy results from molecular docking ligand multifloroside

\begin{tabular}{|l|l|l|l|}
\hline \multirow{2}{*}{ Mode } & \multirow{2}{*}{$\begin{array}{l}\text { Affinity } \\
(\mathrm{kcal} / \mathrm{mol})\end{array}$} & \multicolumn{2}{|l|}{ dist from best mode } \\
\cline { 3 - 4 } & -9.0 & rmsd l.b. & rmsd u.b \\
\hline 1 & -8.1 & 0.000 & 0.000 \\
\hline 2 & -8.0 & 23.015 & 26.043 \\
\hline 3 & -8.0 & 17.974 & 21.492 \\
\hline 4 & -8.0 & 19.640 & 22.907 \\
\hline 5 & -8.0 & 18.376 & 21.809 \\
\hline 6 & -7.9 & 1.581 & 8.468 \\
\hline 7 & -7.7 & 20.440 & 23.896 \\
\hline 8 & -7.6 & 2.004 & 8.804 \\
\hline 9 & \multicolumn{2}{|l}{} \\
\hline
\end{tabular}

The bond energy generated from the Multifloroside docking ligand simulation has a final value of $-9.0 \mathrm{kcal} / \mathrm{mol}$. This value is shown in ligand mode 1 (See table 3). This means that the stable Multifloroside compound is a stable Multifloroside Ligand used as a plasmepsin receptor inhibitor. Because a stable reaction is a reaction that produces negative energy. The more negative the energy produced, the more stable the reaction will be. The reaction that occurs is a spontaneous reaction. So that
Ligand Multifloroside allows it to be used as an antimalaria.

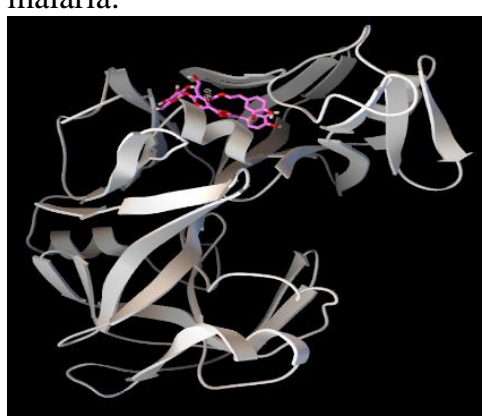

Figure 1: Pose Ligand Multifloroside and Plasmepsin receptor

The bond energy generated from the Trimyristin ligand docking simulation has a final value of -6.4 $\mathrm{kcal} / \mathrm{mol}$. This value is shown in ligand mode 1 (See table 4). This means that the stable Trimyristin compound is a stable Trimyristin ligand used as a plasmepsin receptor inhibitor. Because a stable reaction is a reaction that produces negative energy. The more negative the energy produced, the more stable the reaction will be. The reaction that occurs is a spontaneous reaction. So that the Trimyristin Ligand allows it to be used as an anti-malaria.

Table 4: Gibbs free energy results from molecular docking ligand Trimyristin

\begin{tabular}{|l|l|l|l|}
\hline \multirow{2}{*}{ Mode } & \multirow{2}{*}{$\begin{array}{l}\text { Affinity } \\
(\mathrm{kcal} / \mathrm{mol})\end{array}$} & \multicolumn{2}{|l|}{ dist from best mode } \\
\cline { 3 - 4 } & -6.4 & rmsd l.b. & rmsd u.b \\
\hline 1 & -6.4 & 0.000 & 0.000 \\
\hline 2 & -6.3 & 1.651 & 2.986 \\
\hline 3 & -6.2 & 1.478 & 2.288 \\
\hline 4 & -6.0 & 2.538 & 7.089 \\
\hline 5 & -6.0 & 2.566 & 6.855 \\
\hline 6 & -6.0 & 2.400 & 7.118 \\
\hline 7 & -5.9 & 2.629 & 7.364 \\
\hline 8 & -5.9 & 2.413 & 9.239 \\
\hline 9 & & 18.048 & 22.513 \\
\hline
\end{tabular}

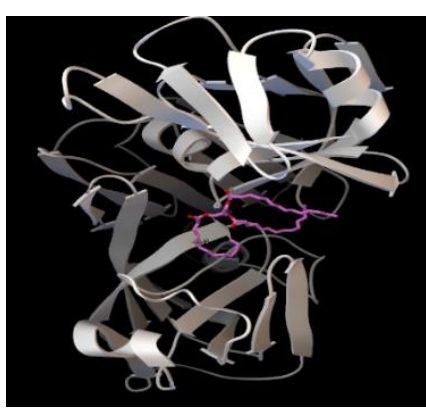

Figure 2: Pose Ligand Trimyristin and Plasmepsin receptor 


\subsection{Hydrogen Bonding}

Hydrogen bonds are parameters that indicate the stability of a reaction. But the effect is actually very small. This parameter affects if the number of hydrogen bonds is large, causing the energy produced to affect the reaction significantly.

If analyzed based on the parameters of hydrogen bonds formed between Multifloroside and Trimyristin ligands against plasmepsin receptors, Multifloroside ligand and Trimyristin ligand compounds each have 1 hydrogen bond formed. For hydrogen bonding on Multifloroside ligand, that is the bond between hydrogen atom and UNK ligand from Plasmepsin compound. Whereas in the Trimyristin ligand the hydrogen bond formed is the bond between the SER218 residue on the plasmepsin receptor and the $\mathrm{HN}$ atom. From the existence of these hydrogen bonds it can be concluded that the Multifloroside ligand and Trimyristin ligand hydrogen bonds do not have a significant effect, because there is only 1 hydrogen bond formed.

\section{CONCLUSIONS}

The Multifloroside ligand and Trimyristin ligand compound is stable when it is docking to the enzyme Plasmepsin. This is analyzed from the free energy of gibbs which has a low value of $-9.0 \mathrm{kcal} /$ mol and for Trimyristin molecules a value of $-6.4 \mathrm{kcal}$ / mol is obtained with 5 replications each. The value of free energy produced by Multifloroside and Trimyristin ligands from the system is negative. This shows that the reaction that occurs is a spontaneous reaction. So it can be concluded the reaction that occurs in a stable system. When compared between Multifloroside ligand and Trimyristin ligand, Multifloroside ligand is more stable than Trimyristin ligand when it is docking to the enzyme Plasmepsin. This is because the value of free energy gibbs produced by Multifloroside ligands is more negative than Trimyristin ligands.

If stability analysis is carried out based on the parameters of hydrogen bonding of Multifloroside ligand and Trimyristin ligand when docking to the enzyme Plasmepsin, then both ligands produce 1 hydrogen bond each. For the Multifloroside ligand, the hydrogen bond formed is UNK-H ligand, whereas for Trimyristin ligand, the hydrogen bond formed is SER218-HN residue. The small number of hydrogen bonds does not affect the stability of the ligand and receptor bonds.

\section{ACKNOWLEDGMENTS}

The authors thanks to Research computational Unit (RCU) Department of Physics Education FKIP UKI, for providing high performance computing to run all dynamics simulations. This research was supported by a research grant from Indonesia Christian University.

\section{REFERENCES}

1. Ali, H. I. et al., 2007. Antitumor studies. Part 3: Design, synthesis, antitumor activity, and molecular docking study of novel 2- methylthio2-amino and 2-(N-substituted amino)-10-alkyl-2deoxo-5- deazaflavins. Bioorganic \& Medicinal Chemistry.

2. Asojo, O. A., et al. 2002. Structures of Ser205 mutant plasmepsin II from Plasmodium falciparum at $1.8 \AA$ in complex with the inhibitors rs367 and rs370. Acta Crystallographica, D. 58 : 2001-2008.

3. Berman, H.M, Westbrook, J., Feng, Z, Gilliland, G., Bhat, T.N., Weissig, H., Shidyyalov, I.N., Bourne, P.E. 2000. The Protein Data Bank. Nucleic Acids Research Vol 28, 235-242

4. Departemen Kesehatan RI. 2006. Pedoman surveilans malaria, Ditjen PP dan PL, Dit. Pengendalian Penyakit Bersumber Binatang, Jakarta.

5. Harijanto. 2000. P. Malaria: Epidemiologi, patologis, manifestasi klinik \& penanganan, Penerbit EGC, Jakarta Harijanto.

6. Kemenkes. 2012. Buku Saku Penatalaksanaan Kasus Malaria. Jakarta: Ditjen Pengendalian Penyakit dan Penyehatan Lingkungan Kementerian Kesehatan RI.

7. Kroemer, R.T. 2003. Molecular modelling probes: docking and scoring, Biochemical Transactions. 31, 980-984

8. Lengauer T, Rarey M. 1996. Computational methods for biomolecular docking. Curr OpinStruct Biol. Jun;6(3):402-6. Review. PubMed PMID: 8804827

9. Lipinski, C. A., Lombardo, F., Dominy, B. W., \& Feeney, P. J. 1997. Experimental and computational approaches to estimate solubility and permeability in drug discovery and development settings. Advanced Drug Delivery

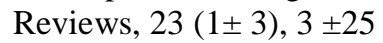

10. Okimoto, N., Futasugi, N., Fuji, H., Suenaga, A., Morimoto, G., et.al. 2009. High Performance Drug Discovery: Computational Screening by 
Combining Docking and Molecular Dynamics Simulation, PloS Computational Biology. Vol 10. $1-13$

11. Redjeki, F., Fauzi, H., \& Priadana, S. (2021). Implementation of Appropriate Marketing and Sales Strategies in Improving Company Performance and Profits. International Journal of Science and Society, 3(2), 31-38. https://doi.org/10.200609/ijsoc.v3i2.314

12. Siswandono, Soekardjo B. 2000. Kimia medisinal pengembangan obat jilid I. Surabaya: Airlangga University Press;1-28:313-336.

13. Soedarto. 2009. Pengobatan Penyakit Parasit. Jakarta: CV. Sagung Seto.

14. WHO, 2015. World Malaria Report 2015. [pdf] Geneva: World Health Organization. Tersedia di: http://www.who.int/malaria/ publications/worldmalaria-report-2015/ report/en/ [15 Juni 2016].

15. Widoyono. 2011. Penyakit Tropis: Epidemiologi, Penularan, Pencegahan \& Pemberantasannya. Kedua ed. Jakarta: Penerbit Erlangga. 